УДК 94(438)

\section{Marcin Danielewski}

Doctor of Philosophy

Historian and archaeologist

Institute of History

Adam Mickiewicz University in Poznań

e-mail: m_danielewski@tlen.pl

\section{GORDS AND CITIES IN POLAND}

IN THE $13^{\text {th }}$ CENTURY IN THE CONTEXT

\section{OF THE THEN SETTLEMENT CHANGES}

The presented article revolves around an important academic issue pertaining to the spatial and chronological relations in the gords and towns of the $13^{\text {th }}$ century, operating in Poland in the then Piast duchies. As part of the considerations, selected examples of gords and towns have been presented from the specific historical countries (Greater Poland, Kuyavia, the Gdansk Pomerania, Masovia, Central Poland, Lesser Poland and Silesia) to illustrate the issues in question. At the same time, attempts have been made to refer these examples to models or spatial relations including towns and older settlement as presented by Marian Rębkowski. These considerations lead to a conclusion that the gords and towns in the $13^{\text {th }}$ century often operated next to each other, fulfilling different functions, at the same time complementing each other.

Keywords: gords, cities, settlement changes, $13^{\text {th }}$ century

${ }^{1}$ In this case, I take into consideration mainly cities as interpreted by Górczak Z. (2016), Lokacje i życie miejskie w średniowiecznej Wielkopolsce. [in:] Archeologia miast wielkopolskich, ed.

H. Machajewski, J. Wrzesiński, Poznań, pp. 13-14.

${ }^{2}$ More on the subject in Danielewski M. (2016). Sieć grodowa na Kujawach oraz jej funkcje od połowy X do końca XIII wieku. Poznań, pp. 304-316.
T $\mathrm{n}$ this text, I present gords and cities in Poland in the $13^{\text {th }}$ century with special emphasis placed on selected central settlements where in the time in question, cities were granted their charters. In the context of research into $13^{\text {th }}$ century Poland, chronological and spatial relations between the old settlement elements (gords) and the newly established cities seem to be of great importance ${ }^{1}$. In the course of my considerations I will also try to provide an answer to the question if cities were a continuation of gords. Another question is if areas with no longer operating early mediaeval gords were included into charter cities and their defensive walls and how popular this solution was ${ }^{2}$. A detailed presentation of the cities and their spatial and chronological relations has been provided only for selected examples from several historical lands.

The number of cities granted charters in the $13^{\text {th }}$ century is very large. Let me refer to data collected by Henryk Samsonowicz whose tentative calculations of city charters in the various parts of Poland in the $13^{\text {th }}$ century were as follows:

- Silesia: 115 city charters.

- Greater Poland: 39 city charters

- Lesser Poland: 26 city charters

- Kujawy and Dobrzyń land: 9 city charters 
${ }^{3}$ Samsonowicz H. (1980).

Tendencje rozwoju sieci miejskiej w Polsce późnośredniowiecznej. Kwartalnik Historii Kultury Materialnej, 28, no.3, pp. 342-344.

${ }^{4}$ Górczak Z. (2002). Najstarsze lokacje miejskie w Wielkopolsce (do 1314 r.) Poznań, pp. 6, 197199.

${ }^{5}$ Chłopocka H. (1965). Lokacja na prawie zachodnioeuropejskim. Rola Gniezna w procesie jednoczenia państwa. [in:] Dzieje Gniezna, ed. J. Topolski, Warszawa, pp. 133-135; BiniaśSzkopek M. (2016). Od grodu do miasta lokacyjnego - Gniezno w XI-XV wieku.[in:] Dzieje Gniezna pierwszej stolicy Polski, ed. J. Dobosz, Gniezno, p. 114.

${ }^{6}$ Górczak Z. (2002). Najstarsze lokacje miejskie, p. 197.

${ }^{7}$ Kaczmarczyk Z. (1953).

Przywilej lokacyjny dla Poznania z r. 1253. Przegląd Zachodni, 9, issues 6-8, pp. 142, 157-158.

${ }^{8}$ Olejnik K. (1982). Z wojennej przeszłości Poznania. Poznań, p. 32; Nowacki B. (2013).

Przemysł I 1220/1221-1257.

Książę suwerennej Wielkopolski. Kraków, pp. 213-214.

${ }^{9}$ Spominki poznańskie. (1962). [in:] Roczniki wielkopolskie, ed. B. Kürbis, cooperation G. Labuda, J. Luciński, R. Walczak, Warszawa 1962, p. 125. Indirectly, this fact may be corroborated by the narration interrupted under 1273 of Rocznik kapituły poznańskiej. Attention was drawn to this fact by Rubczyński W. (1886). Wielkopolska pod rządami synów Władysława Odonica (1239-1279). Rocznik Filarecki, 1, p. 84 . The annals stops before 1273 and the entries were resumed only after 1295. Cf.

Rocznik kapituły poznańskiej. (1962). [in:] Roczniki wielkopolskie, ed. B. Kürbis, cooperation G. Labuda, J. Luciński, R. Walczak, Warszawa, pp. $52,53$.
- Łęczyca and Sieradz lands: 17 city charters

- Gdańsk Pomerania and Chełmno land: 5 city charters

- Mazovia: 4 city charters ${ }^{3}$.

Of course these numbers refer to all city charters including failed attempts. The presented calculations, incomplete and to some extent erroneous as they are (after all, the exact time of granting charters is not always known) show the scale of the growing network of cities in the $13^{\text {th }}$ century. The number of 215 city charters in medieval Poland is truly impressive. It also shows the advancement of urban processes in some of the historical lands. In this case, Silesia is definitely in the lead with its 115 city charters. However, Wielkopolska also enjoyed a growing network of cities. This is a good moment to refer to the findings of Zbyszko Górczak according to which, by 1314 as many as 50 city charters had been successfully granted in Wielkopolska; 30 of these cities were established by the rulers, 11 by secular magnates and 9 by church institutions ${ }^{4}$. These numbers show the scale of the settlement processes in Wielkopolska principalities in the $13^{\text {th }}$ century. As for Wielkopolska, the first recorded city charter was granted to Gniezno before $1243 .{ }^{5}$ The subsequent, oldest city charters in this area are related to Powidz (1243 or 1245?), Międzyrzecz (before 1248), Kostrzyn (1251), Śródka (before 1253? or 1288?), Poznań (1253) and Śrem (1253) 6 .

Let me consider now selected $13^{\text {th }}$ century gords and charter cities in order to establish the forms of spatial and chronological relations prevailing in the specific historical lands incorporated into the then Piast principalities. Of course the presented examples are selective and have the task of presenting various solutions applied to grant city charters in Poland in the time in question.

Two key centres in Wielkopolska: Gniezno and Poznań, provide an extremely interesting gord vs. city juxtaposition. Back in the $10^{\text {th }}$ century the region had hosted huge gord structures. In the course of time, they were extended, sometimes destroyed and revived. However, the second half of the $12^{\text {th }}$ century and the first half of the $13^{\text {th }}$ century were of key importance to the existing gords. For obvious reasons, the time when a specific gord stopped performing its functions to transform into a hillfort may be difficult to determine. In this case, it is much easier to indicate the time of a gord's construction than its decline, especially when the latter was not related to any catastrophe, i.e. a fire or an invasion. On the other hand, the example of the city of Poznan shows that the beginning of a city not always meant the end of a gord's existence. As I have mentioned before, the city charter was granted to Poznan which was established on the left river bank in $1253^{7}$. However, back in 1249 the gord on the island of Ostrów Tumski was thoroughly restored on the initiative of prince Przemysł $\mathrm{I}^{8}$. What is more, in 1274 Brandenburg invaded Wielkopolska and records from Spominki poznańskie (Poznań Reminiscences) indicate that the invaders burnt down Poznań: Theutonici Poznaniam comburunt ${ }^{9}$. However, it is difficult to decide if the reference was made to a charter city, its surrounds 
Figure 1. The modern panorama of Poznan.

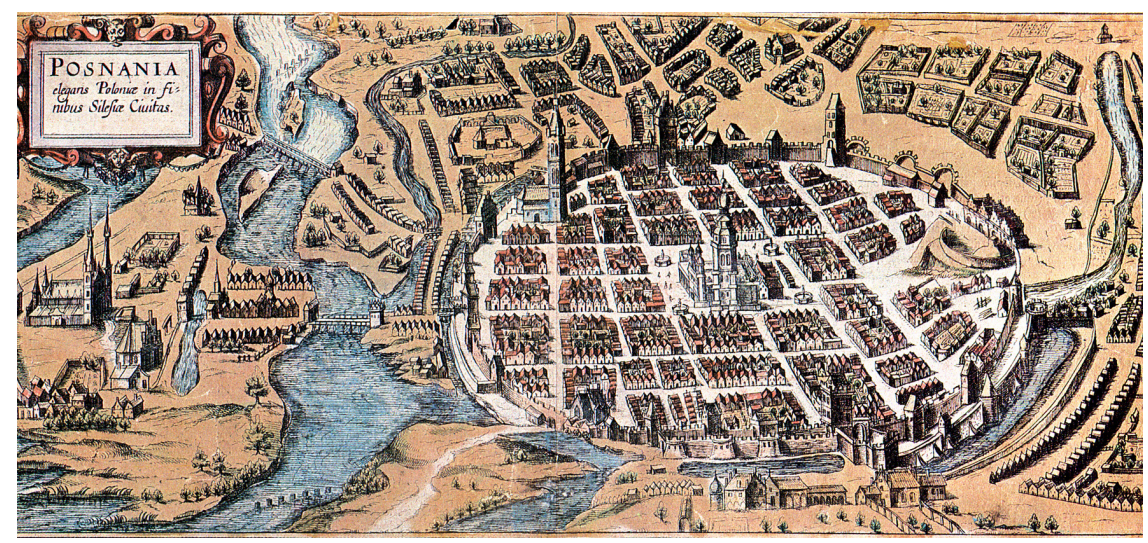

${ }^{10}$ All the three solutions were suggested in the existing literature on the subject: Olejnik K. (1970). Obrona polskiej granicy zachodniej. Okres rozbicia dzielnicowego i monarchii stanowej (1138-1385). Poznań, p. 141; Spors J. (1974). Agresja brandenburska wobec Wielkopolski do 1278 roku. Roczniki Historyczne, 40, p. 119; Hlebionek M. (2010). Bolesław Pobożny i Wielkopolska jego czasów. Kraków, p. 111.

${ }^{11}$ Pilarczyk Z. (1988).

Obronność Poznania w latach 1253-1793. Poznań, pp. 63, 72, 77.

${ }^{12}$ Linette E. (1981). Zamek w Poznaniu. 700 lat dziejów. Warszawa - Poznań, p. 31; Jakubiak A. (1988). Z dziejów fortyfikacji Poznania do końca XVIII wieku. [in:] Poznańskie fortyfikacje, ed. B. Polak, Poznań, p. 35.

${ }^{13}$ Długosz J. (1978). Annales seu cronicae incliti Regni Poloniae, lib. IX, Warszawa, pp. 63-64.

${ }^{14}$ Kaczmarek J. (2005). Między grodem a miastem. Przemiany osadnicze na terenie aglomeracji poznańskiej w X-XIII wieku. [in:] Civitas posnaniensis. Studia $z$ dziejów średniowiecznego Poznania, ed. Z. Kurnatowska, T. or maybe a gord ${ }^{10}$. Irrespective of the scenario, I am of an opinion that the gord and the city coexisted for some time. Especially that the city developed slowly and initially, it was surrounded only by banks made of wood and earth while the construction of the city wall commenced as late as $1275^{11}$. On the other hand, the castle was built on the left river bank in 1274-1288 ${ }^{12}$. This shows how time-consuming was the process of building the city with all its elements. Of course at that time, the status of the importance of the gord declined. Despite this fact, back in the $14^{\text {th }}$ century head of town, Przemko, chose Ostrów Tumski with the Poznan cathedral as a point of opposition against the supporters of prince Władysław Łokietek ${ }^{13}$. This fact shows that the then right-bank Poznan enjoyed significant military values if the supporters of Henry III, Duke of Głogów, chose it for the venue of their defence.

It is therefore clear that ultimately the new city of Poznan was situated in a different location. The point of gravity was transferred from the right to the left bank of the river Warta, in the vicinity of Saint Gotthard settlement, partly St. Adalbert and St. Martin settlements ${ }^{14}$. However, as late as in the second half of the $13^{\text {th }}$ century, the old gord and the new charter city coexisted. In this case, it was a relocation of the centre of the prince's power from the right bank of the river to the left one, extended over time. The huge investments i.e. construction of the new settlement, required the gord's existence for several decades. The prince and his administration needed a seat and for this reason Ostrów Tumski remained a dynamic centre in the second half of the $13^{\text {th }}$ century. Important changes definitely followed completion of the Poznań castle. Once Poznan was settled on the left river bank, the gord remained on the outskirts of the charter city and while it sometimes played a military role, it was no longer part of the prince's or the church's jurisdiction ${ }^{15}$.

A subsequent interesting example is offered by another key city in Wielkopolska, i.e. Gniezno. There, a powerful, multi-section gord was in operation, built in the $10^{\text {th }}$ century ${ }^{16}$ and later on, just like Poznan, Jurek, Poznań, p. 48.

${ }^{15}$ Kóčka-Krenz H. (2015). Ostrów Tumski w Poznaniu w początkach polskiej państwowości. [in:] Pamięć w dębie zachowana, ed. A. Stempin, Poznań, p. 17.

${ }^{16}$ More on this chronology in Sawicki T. (2001). Wczesnośredniowieczny zespół grodowy w Gnieźnie. [in:] Gniezno w świetle ostatnich badań archeologicznych. Nowe fakty. Nowe interpretacje, ed. Z. Kurnatowska, Poznań, pp. 87-126. 


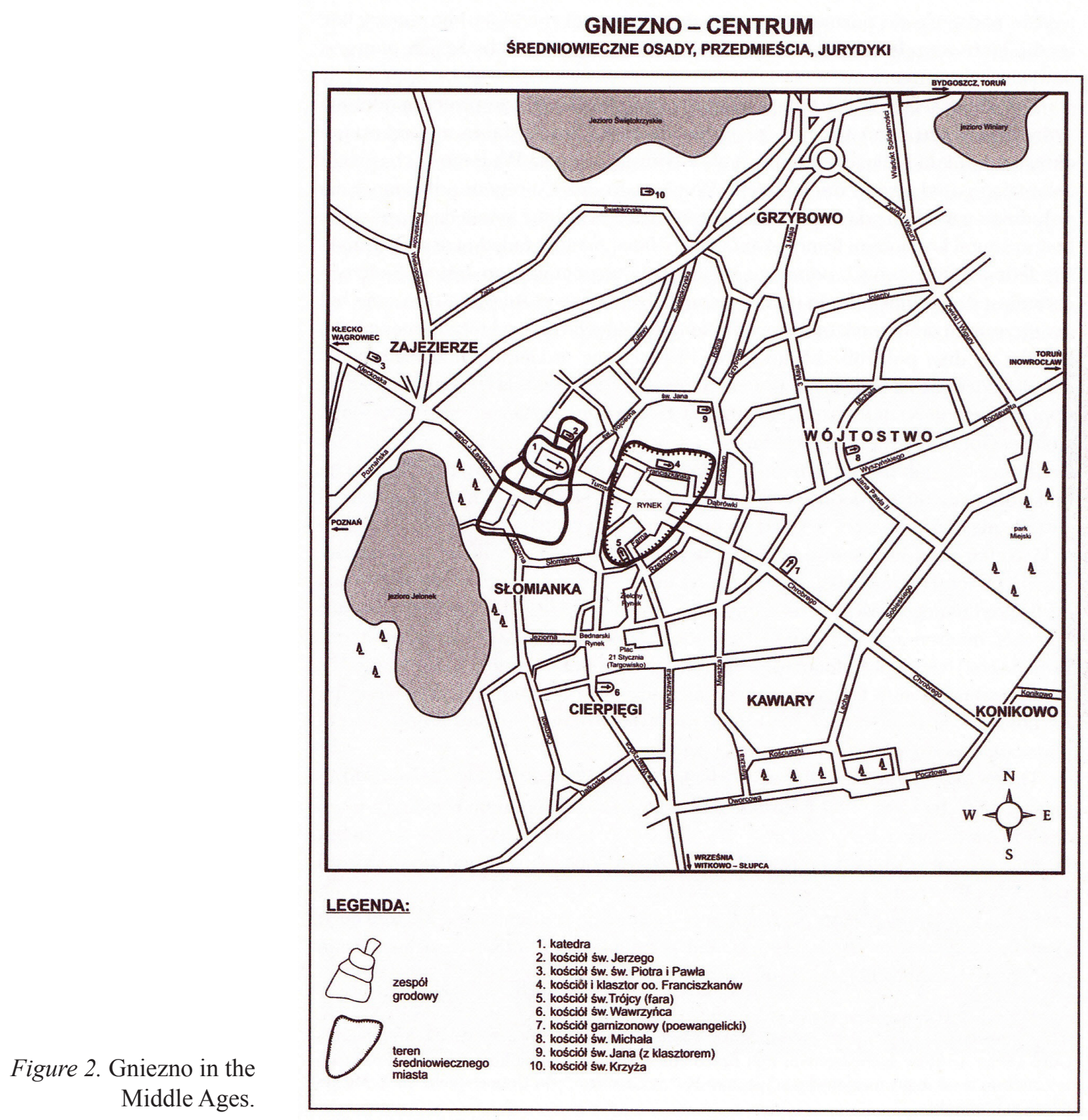

${ }^{17}$ These events are reflected in written materials: Gall Anonim. (1952). Cronica et gesta ducum sive principum Polonorum, ed. K. Maleczyński, Kraków, lib. I, cap. 19, p. 43; Kosmas. (1923). Die chronik der Böhmem des Cosmas von Prag. ed. W. Weinberger, B. Bretholz, Berlin, lib. II, cap. 3, p. 84 .

affected by the invasion by Bretislav I, Duke of Bohemia, in $1038^{17}$. However, Gniezno as a charter city represents a slightly different model of development than the previously analysed example of Poznan. The Gniezno gord would operate as late as in the second half of the $12^{\text {th }}$ century although its further existence was largely impacted by a fire in 1192. As a result of an invasion by Casimir II the Just, a considerable part of the gord was burnt down ${ }^{18}$. Finally, in the northern part of Góra Lecha (Lech's Hill) a castle was built. The brick castle was raised in 1234-1237 on the initiative of Władysław Odonic and was strictly related to the city charter ${ }^{19}$. The latter was to be granted in the

${ }^{18}$ Rocznik kapituły gnieźnieńskiej 1192-1247. (1962). [in:] Roczniki wielkopolskie, ed. B. Kürbis in cooperation with G. Labuda, J. Luciński and R. Walczak, Warszawa, p. 3. Cf. Chłopocka H. (1965). Gniezno głównym ośrodkiem polityczno-administracyjnym Wielkopolski do połowy XIII w. [in:] Dzieje Gniezna, ed. J. Topolski, Warszawa, pp. 122-123.

${ }^{19}$ Sawicki T. (2001). Z badań nad zamkiem książęcym na Górze Lecha w Gnieźnie. [in:] Gniezno w świetle ostatnich badań archeologicznych. Nowe fakty. Nowe interpretacje, ed. Z. Kurnatowska, Poznań, pp. $223-224$. 
Figure 3. Distribution of archaeological sites from the Middle Ages, the vicinity of Inowrocław.

${ }^{20}$ Biniaś-Szkopek M. (2016). Od grodu do miasta lokacyjnego, $\mathrm{p}$. 114.

${ }^{21}$ More on the subject in Danielewski M. (2016). Gniezno i okolice do 1038 roku. [in:] Dzieje Gniezna pierwszej stolicy Polski, ed. J. Dobosz, Gniezno, p. 37.

${ }^{22}$ Grabarczyk T., KowalskaPietrzak A., Nowak T. (2003). Dzieje miasta do końca XVI wieku. [in:] Łęczyca. Dzieje miasta $w$ średniowieczu $i$ w XX wieku. Suplement do monografii miasta, ed. J. Szymczak, Łęczyca - Łódź, p. 11; Szymczak J. (2012). Źródła pisane do dziejów średniowiecznej Łęczycy. [in:] Źródła, wykopaliska mapy. Źródła do dziejów Łęczycy, ed.

L. Sztompka, M. Żemigała, Łęczyca, pp. 18-19; Kajzer L. (2013). Łęczyca trzecia albo kazimierzowska. Garść uwag. Kwartalnik Historii Kultury Materialnej, 60, pp. 142-143.

${ }^{23}$ Jurek T. (2014). Pierwsze wieki historii Łęczycy. [in:] Początki Łęczycy, vol. 3 (W kręgu historii i historii sztuki), ed. R. Grygiel, T. Jurek, Łódź, pp. 87-88.

${ }^{24}$ Jurek T. (2014). Pierwsze wieki historii Łęczycy, pp. 68, 73, 88-92. early medieval open settlement ${ }^{21}$.

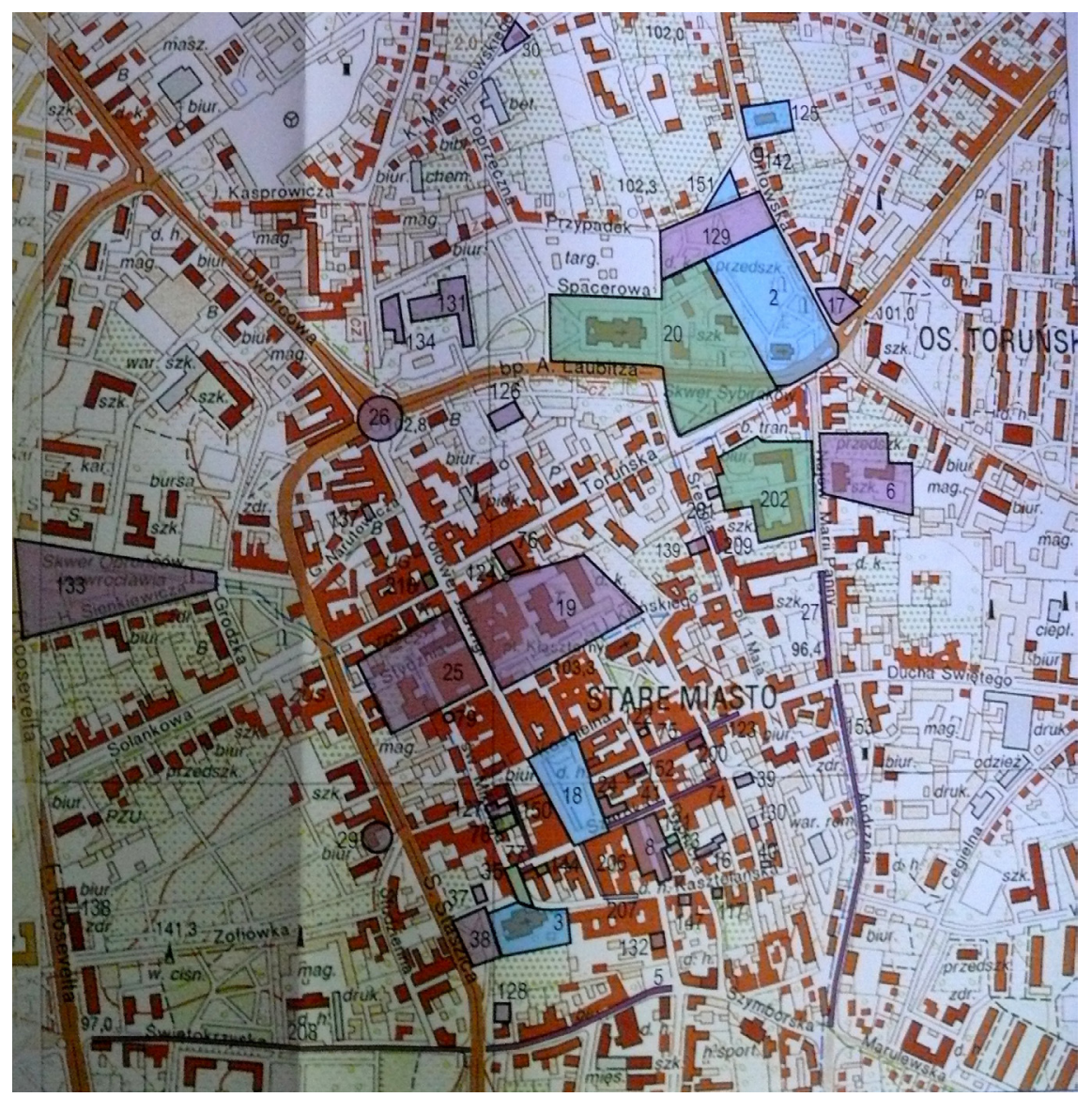

late 1130 s or the very beginning of the 1140 s and has been typically attributed to the above mentioned prince Władysław Odonic or, less frequently, Bolesław the Pious ${ }^{20}$. From my point of view, the location of the new city is of key importance; it was situated in the vicinity of Wzgórze Panieńskie (to the south-east of the gord) replacing an older,

Łęczyca in Central Poland is another very interesting example of the gord-city relation. In this case. the political, economic, administrative and military centres were shifted from Tum towards Łęczyca. The time of the first charter granted to Łęczyca is still under discussion. Typically in historiography (e.g. works of Tadeusz Grabarczyk, Anna Kowalczyk-Pietrzak, Tadeusz Nowak, Jan Szymczak and Leszek Kajzer) the charter has been attributed to prince Casimir I of Kuyavia while the event was to take place between 1247 and $1267^{22}$. Lately, Tomasz Jurek put forward a hypothesis that the charter had been granted during the reign of Konrad I of Masovia, perhaps around 1235 ${ }^{23}$. This initiative would be related to a settlement located west of the Bzura river valley, in the area near the so-called Old City (now a part of the city referred to as Waliszew $)^{24}$. In this case, I am not attempting to establish the time of the charter although in my opinion, in the light 
${ }^{25}$ Grygiel R., Jurek T. (2014).

Zakończenie. Początki Łęczycy: dyskurs archeologa i historyka. [in:] Początki Łęczycy, vol. 3 (W kręgu historii i historii sztuki), ed. R. Grygiel, T. Jurek, Łódź, pp. 309-310.

${ }^{26}$ The other charter was related to prince Kazimierz son of Kazimierz, see Jurek T. (2014). Pierwsze wieki historii Łęczycy, pp. 94-95.

${ }^{27}$ Lalik T. (1993). Sandomierz w świetle źródeł pisanych. [in:] Sandomierz. Badania 19691973, vol. 1, ed. S. Tabaczyński, Warszawa, p. 61.

${ }^{28}$ Codex diplomaticus Poloniae. (1858). vol. III, ed. J. Bartoszewicz, Warszawa, no. 63. ${ }^{29}$ Florek M. (2005).

Sandomierski ośrodek grodowomiejski w średniowieczu.

Przemiany przestrzenne i funkcjonalne. Warszawa, pp. 41, 42, 64, Figure 22.

${ }^{30}$ Florek M. (2005).

Sandomierski ośrodek grodowomiejski, pp. 45-46.

${ }^{31}$ Joannis de Czarnkow. (1961).

Chronicon Polonorum, ed.

J. Szlachtowski, Warszawa, cap. 3, p. 625. Compare comments on the subject: Miłobędzki A. (1967). Zamek sandomierski. [in:] Studia sandomierskie. Materiaty do dziejów miasta Sandomierza i regionu sandomierskiego, ed. T. Wąsowicz, J. Pazdur, Sandomierz, pp. 250-255. ${ }^{32}$ Jasiński K. (1978). Gdańsk w okresie samodzielności politycznej Pomorza Gdańskiego. [in:] Historia Gdańska, vol. 1 (by 1454), ed. E. Cieślak, Gdańsk, pp. 276-277; Jasiński K. (1996). Początki gminy miejskiej w Gdańsku. Na marginesie badań nad dokumentem Świętopełka dla dominikanów gdańskich

Z 1227 r. [in.] Studia nad dziejami miast i mieszczaństwa w średniowieczu. Studia ofiarowane Profesorowi Antoniemu Czacharowskiemu w sześćdziesiąta piata rocznicę urodzin i czterdziestolecie pracy naukowej, ed. R. Czaja, J. Tandecki, Toruń, p. 57.

${ }^{33}$ Paner H. (2015). Rozwój przestrzenny wczesnośredniowiecznego Gdańska w świetle źródeł archeologicznych. Archaeologia Historica Polona, 23, pp. 140-145.

${ }^{34}$ Paner H. (2015). Rozwój przestrzenny, pp. 145-154 (especially 153-154). Cf. Labuda G. (1972). Rozwój gospodarki wiejskiej i początki miast samorządowych. [in:] Historia Pomorza, vol. 1 (by 1466), ed. G. Labuda, Poznań, pp. 513-515. 
Figure 4. The oldest urban locations from medieval Kuyavia.

${ }^{35}$ Paner H. (2004). Nowe źródła archeologiczne do dziejów wczesnośredniowiecznego Gdańska. [in:] Archaeologia et historia Urbana, ed. R. Czaja, G. Nawrolska, M. Rębkowski, J. Tandecki, Elbląg, p. 166, Figure 1.

${ }^{36}$ Trzeciecki M. (2011).

Początki Płocka. [in:] Płock wczesnośredniowieczny, ed. A. Gołembnik, Warszawa, p. 97. ${ }^{37}$ Gołembnik A. (2011). Rozwój osadnictwa otwartego i pierwsza lokacja miasta. [in:] Plock wczesnośredniowieczny, ed.

A. Gołembnik, Warszawa, pp. 267-269; Trzeciecki M. (2011). Gród na Wzgórzu Tumskim. [in:] Płock wczesnośredniowieczny, ed. A. Gołembnik, Warszawa, pp. 141-144, 146.

${ }^{38}$ Kodeks dyplomatyczny

Księstwa Mazowieckiego. (1962). ed. T. Lubomirski, Warszawa, no. 11. Cf. comments on the subjects made by Pazyra S. (1959). Geneza i rozwój miast mazowieckich. Warszawa, pp. 90-93.

${ }^{39}$ Gołembnik A. (2011). Rozwój osadnictwa otwartego, pp. 270-276, Figure 149, 150.

${ }^{40}$ Polak Z. (2011). Płock średniowieczny - kontynuacja czy nowa jakość? [in:] Płock wczesnośredniowieczny, ed. A. Gołembnik, Warszawa, p. 369.

${ }^{41}$ Polak Z. (2011). Płock średniowieczny, p. 369. an older, early-medieval open settlement had been. Bolesław the Pious ${ }^{41}$.

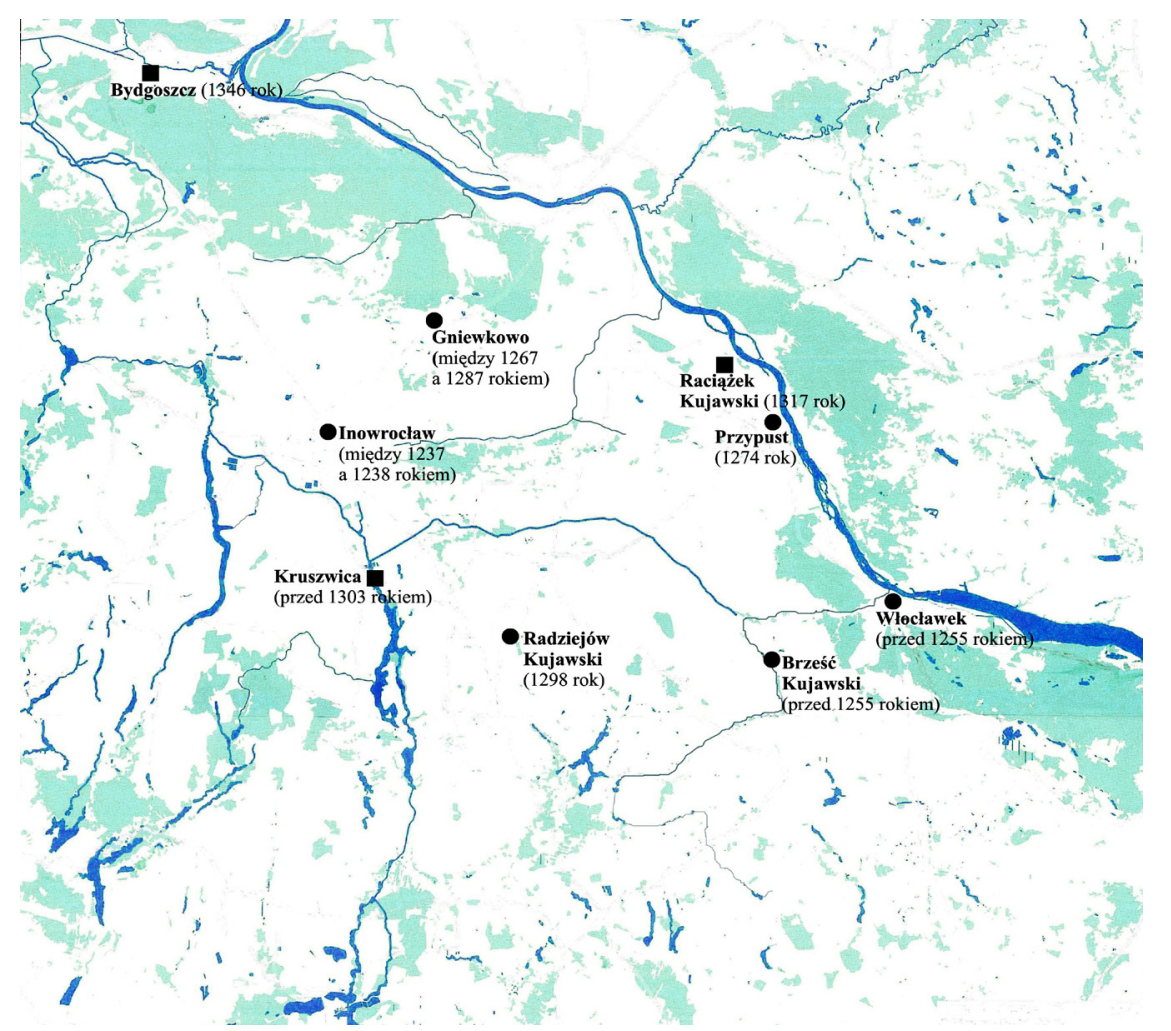

the river Mołtawa, north-east of the later charter city ${ }^{35}$. Therefore, the city was originated at a small distance from the gord where previously

Another example of the spatial and chronological relations is Płock, located on the river Vistula in Mazovia. It is an altogether different model of using an old gord in the settlement processes related to granting a city charter. The Płock gord whose origin dates back to the late $10^{\text {th }}$ century ${ }^{36}$ enjoyed its peak importance during the reign of Władysław I Herman and his son Bolesław III Wrymouth. However, at the end of the $12^{\text {th }}$ and the beginning of the $13^{\text {th }}$ centuries, the development of the gord slowed down significantly, most probably as the aftermath of the numerous Russian and Prussian raids ${ }^{37}$. Finally, in 1237 the first charter was granted to the city and it seems extremely interesting. Its existence is corroborated by a document issued by Piotr, the bishop of Płock, at the request of prince Konrad I of Masovia ${ }^{38}$. The new charter city incorporated the area located to the north-east of the gord. At the same time, within this charter was also the bishop's suburbium. On the other hand, the actual gord was outside the charter city ${ }^{39}$ and ultimately replaced with a castle (by slightly narrowing down the embankment) which served as the prince's seat. This investment was stepped up most probably as late as 1290 by Bolesław II of Masovia ${ }^{40}$. Before that, the role of the prince's seat operating in the vicinity of the city granted a charter in 1237 was fulfilled by a gord whose defensive banks made of wood and earth might have been rebuilt in 1262 by 
+ Biskup M. (1978). Dzieje miasta W średniowieczu (od końca XII w. do 1466 r.) [in:] Dzieje Inowrocławia, vol. I, ed. M. Biskup, Warszawa - Poznań Toruń, pp. 139-141.

${ }^{43}$ I referred to these premises in 2016, see Danielewski M. (2016). Sieć grodowa, pp. 305306.

${ }^{44}$ Mikołajczak E. (2017).

Inowrocław w czasach

Kazimierza Konradowica (12301267). [in:] Książe Kazimierz

Konradowic i Kujawy jego czasów, ed. D. Karczewski, Kraków, pp. 14-16.

${ }^{45}$ Rocznik kapituły gnieźnieńskiej 1192-1247. (1962), p. 4.

${ }^{46}$ Biskup M. (1978). Dzieje miasta, p. 149.

${ }^{47}$ Woźniak M. (2007).

Inowrocław - stanowiska 2, 20 i 6 (AZP 44-40 st. na obszarze 45, 46 i 47) sprawozdanie $z$ nadzorów archeologicznych oraz $\mathrm{z}$ ratowniczych badań archeologicznych prowadzonych w związku z przebudową skrzyżowania w ciągu drogi krajowej nr 15 w Inowrocławiu. Inowrocław, text stored in Jan Kasprowicz Museum in Inowrocław.

${ }^{48}$ Cofta-Broniewska A. (1974).

Wczesnośredniowieczna warzelnia soli w Inowrocławiu. Ziemia Kujawska, 4, pp. 5-13.

${ }^{49}$ Cofta-Broniewska A. (1972).

Badania archeologiczne w Inowrocławiu w 1967 roku. Sprawozdania Archeologiczne, 24, pp. 164-165; Guldon Z. (1974). Dzieje hutnictwa żelaznego na Kujawach i w ziemi dobrzyńskiej do XVI wieku. Ziemia Kujawska, 4, p. 36; Cofta-Broniewska A. (1978). Inowrocław i jego rejon w pradziejach i we wczesnym średniowieczu. [in:] Dzieje Inowrocławia, vol. 1, ed. M. Biskup, Warszawa - Poznań Toruń, p. 119.
Let me now shift my attention to Kuyavia where Inowrocław was the region's most important city in the $13^{\text {th }}$ century and the capital of Casimir I of Kuyavia's principality. According to a hypothesis advanced by Marian Biskup, the charter could have been granted between 1237 and 1238. According to the scholar, in 1238 at the latest, Inowrocław was granted a charter with Magdeburg rights ${ }^{42}$. Unfortunately, the charter has not survived to our times and therefore M. Biskup's line of reasoning is based only on indirect premises ${ }^{43}$.

While the arguments and reasoning of $\mathrm{M}$. Biskup seem rather convincing, due to the lack of clarity of the time when the city was granted a charter, it is difficult to have an opinion on the relations between the charter city with German rights and the hypothetical gord. The situation is even more complicated in the light of the fact that the alleged Inowrocław gord has not been discovered so far. It is also quite possible that a stronghold never actually existed in Inowrocław. Before the charter, the city was situated around St. Mary's church from the $12^{\text {th }}$ century and the local market place ${ }^{44}$. Of special interest is information included in Rocznik kapituly gnieźnieńskiej (Gniezno Chapter Church's Annals) about the invasion by Svatopluk, a Pomeranian prince, in 1238 or 1239. The records differentiate between the church (most probably St. Mary's church) and the city ${ }^{45}$. The area of the so-called Old City, referred to as such by M. Biskup and others ${ }^{46}$, is therefore a separate settlement. Bearing this in mind, archaeological excavations from the area of the above mentioned church are of special importance; later on it was not incorporated into the charter city. Field research confirms the importance of the venue classified by archaeologists as site 2. Suffice it to say, in the area closest to the church, in 2007 numerous archaeological objects were excavated related to settlement from the $12^{\text {th }}$ century and the first half of the $13^{\text {th }}$ century. What is more, these premises were destroyed in a fire as testified by layers of ash, burnt top layer of the floor and ceramics ${ }^{47}$. Quite possibly, these are the effects of Svatopluk's raid.

Slightly further away from the church, salt works were discovered from the $11^{\text {th }}$ and the $12^{\text {th }}$ centuries $^{48}$. The area was largely populated by craftsmen and other workers in the vicinity of the market place from the late $11^{\text {th }}$ and the early $12^{\text {th }}$ centuries with traces of smithery and steel mills ${ }^{49}$. At present, the former salt works and settlement have been classified as archaeological site no. 20. It is worth noting that in this site, traces of a fire have also been found, sometimes amounting to $40 \mathrm{~cm}^{50}$.

South of St. Mary's church is located site no. 6 which was surveyed in 2014. The discovered archaeological artefacts including one semi-dugout can be dated back to the end of the $12^{\text {th }}$ century and the first half of the $13^{\text {th }}$ century ${ }^{51}$. This concentration is a part of the southern end of Inowrocław before it was granted a charter. The subsequent planned archaeological research may provide an ultimate explanation.

\footnotetext{
${ }^{50}$ Woźniak M. (2012). Inowrocław stanowisko 20 (AZP 44-40 st. na obszarze 46) sprawozdanie z nadzorów archeologicznych. Inowrocław, opracowanie w zbiorach Muzeum Jana Kasprowicza w Inowrocławiu.

${ }^{51}$ Woźniak M. (2014). Inowrocław - stanowisko 6 sprawozdanie z ratowniczych badań wyprzedzających w roku 2014 (obszar AZP 44-40/189). Inowrocław, text stored in Jan Kasprowicz Museum in Inowrocław.
} 
${ }^{52}$ This issue was discussed in more details in 2015, see Danielewski M. (2015). Przyczynek do nowych badań nad kasztelanią inowrocławską w XIII-XIV wieku. Wielkopolskie Sprawozdania Archeologiczne, 16, pp. 210-212, 214.

\section{${ }^{53}$ Zientara B. (1997). Henryk} Brodaty i jego czasy, afterword by M. Dygo, Warszawa, pp. 155158.

${ }^{54}$ Młynarska-Kaletynowa M. (1986). Wrocław w XII-XIII wieku. Przemiany społeczne i osadnicze. Wrocław, pp. 100, 124-128.

${ }^{55}$ More information about the gord in Rzeźnik P. (2000). Gród wrocławski około roku 1000. [in:] Śląsk około roku 1000, ed. M. Młynarska-Kaletynowa, E. Małachowicz, Wrocław, pp. 139148.

${ }^{56}$ Lately, this opinion was repeated by Mikołajczak E. (2017). Inowrocław w czasach Kazimierza Konradowica, p. 17.

${ }^{57}$ Piekalski J. (1999). Od Kolonii do Krakowa. Przemiana Topografii wczesnych miast. Wrocław, pp. 199-200.

${ }^{58}$ Piekalski J. (1999). Od Kolonii do Krakowa, pp. 207-208.

${ }^{59}$ Rębkowski M. (2001).

Pierwsze lokacje miast w księstwie zachodniopomorskim. Przemiany przestrzenne $\mathrm{i}$ kulturowe. Kołobrzeg, pp. 53-58.
The area of Inowrocław before it was granted a charter with the captured northern, western and partly southern limits and the city's focal point i.e. St. Mary's church, have been quite well recognised by archaeologists. The area can be regarded a gord-less settlement preceding the city charter ${ }^{52}$. The charter city developed in stages and was established in a place where the former settlement had been scarce and ancient. Therefore, the city was established in a population-free area, where a robust centre with St. Mary's church and a market place was left outside the new charter city.

Silesia and the city of Wrocław (Breslau) seem extremely interesting in the context of these considerations. The city was granted three possible charters.

The first charter was most probably initiated by Henry the Beard$\mathrm{ed}^{53}$, the second was granted around 1242 (on the initiative of Bolesław II Rogatka) while the third one was granted in 1261 (on the initiative of Henry III the White and Ladislaus of Salzburg $)^{54}$. The charter city was established on the outskirts of an older settlement, on the left bank of the Oder while the former gord remained outside the city structure ${ }^{55}$. Of special interest is the fact that the new charter city was established in an area free from older settlement. This is a clear analogy to Inowrocław. Topped with the fact that prince Casimir I of Kuyavia, the initiator of Inowrocław's charter, drew on the Silesian model (or at least this is the version adopted in Polish historiography ${ }^{56}$ ), the similarities in both charters can be corroborated. It is also worth adding that after Wrocław was granted a charter, it extended significantly in the second half of the $13^{\text {th }}$ century and absorbed the crafts and trade settlement located east of the city, near St. Adalbert's church ${ }^{57}$. Outside the city, in Ostrów Tumski, remained the centre of religious and secular power. However, soon, during the reign of Henryk IV Probus in the 1280s, works started on the new prince's residence located on the left bank of the Oder, on the outskirts of the city and incorporated into the city fortifications ${ }^{58}$. This fact shows that back at that time, the gord in Ostrów Tumski did not play an important role.

With the above considerations in mind, I can present the models of spatial relations between the cities and the gords as well as older settlements. In this case the models created by Marian Rębkowski for medieval cities in Western Pomerania prove helpful ${ }^{59}$. Model I would include charter cities established by replacing older settlements. Three variants have been identified:

A. A charter city including a part of the suburbium or the suburbium settlement.

B. A charter city includes not only one suburbium but also the gord without the remaining parts (suburbia) of the early medieval complex.

C. A charter city gradually absorbs all the parts of the older settlement.

As part of model II, a charter city would grow at a distance from the gord as a result of which, the settlement centre was shifted to another area. In this case two variants would exist:

A. A charter city occupies a previously unpopulated area.

B. A charter city is shifted with respect to the gord and situated where the old village/settlement was. 
Finally, in model III the city was granted a charter without any relations to the older gord settlement.

Each model has some imperfections and yet they are worth using in the previously analysed cities. In the light of the above considerations one can conclude that the charter city of Inowrocław was a typical example of model III i.e. a city established without relations to the older gord settlement. The charter city of Poznan needs to be classified differently as it definitely fits model II, variant B. The city granted a charter by Przemysł I on the left bank of the river Warta replaced old villages: Saint Gotthard, partly St. Adalbert and St. Martin. The same classification should be applied to the charter city of Gniezno. The city was situated on Wzgórze Panieńskie, to the south-west of the gord complex, to replace the existing open settlement. The model in question can be also applied to Gdańsk, Łęczyca and Sandomierz where the cities were built in venues of former open settlement. The same model II but variant A can be applied to the charter city of Wrocław established in a previously unpopulated area, at a distance to the gord. On the other hand, the example of Płock granted a charter in 1237 is a typical solution from model I, variant $\mathrm{A}$. The new charter city incorporated partly the suburbium, leaving only the gord outside its limits. Therefore, there is no single, typical model of how cities were formed in the $13^{\text {th }}$ century in Piast principalities. Each time, the process of granting a charter was conditioned by the local factors, predominantly settlement-related and definitely affected the emergence and growth of cities.

To sum up the above considerations, I must conclude that the chronological and spatial relations between gords and cities in the $13^{\text {th }}$ century still require further research. In the face of scarce written sources little is known about many $13^{\text {th }}$ century cities, the space they occupied and the development within the city walls. To date, the issues have also been neglected by archaeologists, narrowed down to works accompanying renovations or construction investments. Archaeological research, carried out selectively and randomly, does not contribute to a better understanding of the specific $13^{\text {th }}$ century cities. Some of the smaller cities are very poorly researched which also precludes any conclusions on urban space. Therefore, the issue of chronological and spatial relations between gords and cities has not been thoroughly surveyed and it may remain so for a long time. Despite these distressing reflexions, one should not avoid presentation of conclusions resulting from these considerations with the most important of them i.e. observations related to the times before granting the charters. This comparison suggests that at least several models of spatial relations between gords and cities existed. In my opinion, any charters followed by development (outside walls, a classical grid of streets, the shape of the market and the distribution of subsequent house lots) necessitated a preferably poorly populated and undeveloped land. There was no need to adjust the streets to the already existing distribution of the subsequent buildings. This may be the reason for the distance between cities established on the German law from the local gords (Poznań, Gdańsk, Gniezno, Sandomierz). This does not indicate that each time, unpopulated areas were sought for charter cities although such situations occurred (Inowrocław). In the future, this issue necessitates further detailed research into specific areas like fragmented principalities 
or the settlement-related activities on the part of the specific princes. Such analyses could indicate which models of the spatial relations between cities and gords are typical of specific principalities and which solutions were employed by the specific rulers. In my opinion, the development of historical science will allow to provide answers to these questions in the future.

\section{Bibliography:}

Biniaś-Szkopek M. (2016). Od grodu do miasta lokacyjnego - Gniezno w XI-XV wieku. [in:] Dzieje Gniezna pierwszej stolicy Polski, ed. J. Dobosz, Gniezno, pp. 93-159.

Biskup M. (1978). Dzieje miasta w średniowieczu (od końca XII w. do 1466 r.) [in:] Dzieje Inowroctawia, vol. I, ed. M. Biskup, Warszawa Poznań - Toruń, pp. 129-236.

Chłopocka H. (1965). Gniezno głównym ośrodkiem polityczno-administracyjnym Wielkopolski do połowy XIII w. [in:] Dzieje Gniezna, ed. J. Topolski, Warszawa, pp. 118-132.

Chłopocka H. (1965). Lokacja na prawie zachodnioeuropejskim. Rola Gniezna w procesie jednoczenia państwa. [in:] Dzieje Gniezna, ed. J. Topolski, Warszawa, pp. 133-156.

Codex diplomaticus Poloniae. (1858). vol. III, ed. J. Bartoszewicz, Warszawa.

Cofta-Broniewska A. (1972). Badania archeologiczne w Inowrocławiu w 1967 roku. Sprawozdania Archeologiczne, 24, pp. 163-174.

Cofta-Broniewska A. (1978). Inowrocław i jego rejon w pradziejach i we wczesnym średniowieczu. [in:] Dzieje Inowroctawia, vol. 1, ed. M. Biskup, Warszawa - Poznań - Toruń, pp. 57-128.

Cofta-Broniewska A. (1974). Wczesnośredniowieczna warzelnia soli w Inowrocławiu. Ziemia Kujawska, 4, pp. 5-13.

Danielewski M. (2016). Gniezno i okolice do 1038 roku. [in:] Dzieje Gniezna pierwszej stolicy Polski, ed. J. Dobosz, Gniezno, pp. 15-73.

Danielewski M. (2015). Przyczynek do nowych badań nad kasztelanią inowrocławską w XIII-XIV wieku. Wielkopolskie Sprawozdania Archeologiczne, 16, pp. 207-215.

Danielewski M. (2016). Sieć grodowa na Kujawach oraz jej funkcje od połowy X do końca XIII wieku. Poznań.

Długosz J. (1978). Annales seu cronicae incliti Regni Poloniae, lib. IX, Warszawa.

Florek M. (2005). Sandomierski ośrodek grodowo-miejski w średniowieczu. Przemiany przestrzenne i funkcjonalne. Warszawa.

Gall Anonim. (1952). Cronica et gesta ducum sive principum Polonorum, ed. K. Maleczyński, Kraków.

Gołembnik A. (2011). Rozwój osadnictwa otwartego i pierwsza lokacja miasta. [in:] Plock wczesnośredniowieczny, ed. A. Gołembnik, Warszawa, pp. 217-278.

Górczak Z. (2016), Lokacje i życie miejskie w średniowiecznej Wielkopolsce. [in:] Archeologia miast wielkopolskich, ed. H. Machajewski, J. Wrzesiński, Poznań, pp. 11-32.

Górczak Z. (2002). Najstarsze lokacje miejskie w Wielkopolsce (do 1314 r.) Poznań.

Grabarczyk T., Kowalska-Pietrzak A., Nowak T. (2003). Dzieje miasta do końca XVI wieku. [in:] Lęczyca. Dzieje miasta w średniowieczu i w XX wieku. Suplement do monografii miasta, ed. J. Szymczak, Łęczyca - Łódź, pp. 9-104.

Grygiel R., Jurek T. (2014). Zakończenie. Początki Łęczycy: dyskurs archeologa i historyka. [in:] Początki Łęczycy, vol. 3 (W kręgu historii i historii sztuki), ed. R. Grygiel, T. Jurek, Łódź, pp. 303-311. 
Guldon Z. (1974). Dzieje hutnictwa żelaznego na Kujawach i w ziemi dobrzyńskiej do XVI wieku. Ziemia Kujawska, 4, pp. 31-45.

Hlebionek M. (2010). Bolesław Pobożny i Wielkopolska jego czasów. Kraków.

Jakubiak A. (1988). Z dziejów fortyfikacji Poznania do końca XVIII wieku. [in:] Poznańskie fortyfikacje, ed. B. Polak, Poznań, pp. 33-64.

Jasiński K. (1978). Gdańsk w okresie samodzielności politycznej Pomorza Gdańskiego. [in:] Historia Gdańska, vol. 1 (by 1454), ed. E. Cieślak, Gdańsk, pp. 271-297.

Jasiński K. (1996). Początki gminy miejskiej w Gdańsku. Na marginesie badań nad dokumentem Świętopełka dla dominikanów gdańskich z 1227 r. [in:] Studia nad dziejami miast i mieszczaństwa w średniowieczu. Studia ofiarowane Profesorowi Antoniemu Czacharowskiemu w sześćdziesiata piata rocznicę urodzin i czterdziestolecie pracy naukowej, ed. R. Czaja, J. Tandecki, Toruń, pp. 43-57.

Joannis de Czarnkow. (1961). Chronicon Polonorum, ed. J. Szlachtowski, Warszawa.

Jurek T. (2014). Pierwsze wieki historii Łęczycy. [in:] Poczatki Łęczycy, vol. 3 (W kręgu historii i historii sztuki), ed. R. Grygiel, T. Jurek, Łódź, pp. 7-196.

Kaczmarczyk Z. (1953). Przywilej lokacyjny dla Poznania z r. 1253. Przegląd Zachodni, 9, issues 6-8, pp. 142-166.

Kaczmarek J. (2005). Między grodem a miastem. Przemiany osadnicze na terenie aglomeracji poznańskiej w X-XIII wieku. [in:] Civitas posnaniensis. Studia z dziejów średniowiecznego Poznania, ed. Z. Kurnatowska, T. Jurek, Poznań, pp. 43-58.

Kajzer L. (2013). Łęczyca trzecia albo kazimierzowska. Garść uwag. Kwartalnik Historii Kultury Materialnej, 60, pp. 383-393.

Kodeks dyplomatyczny Księstwa Mazowieckiego. (1962). ed. T. Lubomirski, Warszawa.

Kosmas. (1923). Die chronik der Böhmem des Cosmas von Prag. ed. W. Weinberger, B. Bretholz, Berlin.

Kóčka-Krenz H. (2015). Ostrów Tumski w Poznaniu w początkach polskiej państwowości. [in:] Pamięć $w$ dębie zachowana, ed. A. Stempin, Poznań, pp. 11-25.

Labuda G. (1972). Rozwój gospodarki wiejskiej i początki miast samorządowych. [in:] Historia Pomorza, vol. 1 (by 1466), ed. G. Labuda, Poznań, pp. 495-521.

Lalik T. (1993). Sandomierz w świetle źródeł pisanych. [in:] Sandomierz. Badania 1969-1973, vol. 1, ed. S. Tabaczyński, Warszawa, pp. 49-72.

Linette E. (1981). Zamek w Poznaniu. 700 lat dziejów. Warszawa Poznań.

Mikołajczak E. (2017). Inowrocław w czasach Kazimierza Konradowica (1230-1267). [in:] Książe Kazimierz Konradowic i Kujawy jego czasów, ed. D. Karczewski, Kraków, pp. 13-32.

Miłobędzki A. (1967). Zamek sandomierski. [in:] Studia sandomierskie. Materiaty do dziejów miasta Sandomierza i regionu sandomierskiego, ed. T. Wasowicz, J. Pazdur, Sandomierz, pp. 245-276.

Młynarska-Kaletynowa M. (1986). Wrocław w XII-XIII wieku. Przemiany społeczne i osadnicze. Wrocław.

Nowacki B. (2013). Przemysł I 1220/1221-1257. Książę suwerennej Wielkopolski. Kraków.

Olejnik K. (1970). Obrona polskiej granicy zachodniej. Okres rozbicia dzielnicowego i monarchii stanowej (1138-1385). Poznań.

Olejnik K. (1982). Z wojennej przeszłości Poznania. Poznań.

Paner H. (2004). Nowe źródła archeologiczne do dziejów wczesnośredniowiecznego Gdańska. [in:] Archaeologia et historia Urbana, ed. R. Czaja, G. Nawrolska, M. Rębkowski, J. Tandecki, Elbląg, pp. 165-173. 
Paner H. (2015). Rozwój przestrzenny wczesnośredniowiecznego Gdańska w świetle źródeł archeologicznych. Archaeologia Historica Polona, 23, pp. 139-161.

Pazyra S. (1959). Geneza i rozwój miast mazowieckich. Warszawa.

Piekalski J. (1999). Od Kolonii do Krakowa. Przemiana Topografii wczesnych miast. Wrocław.

Pilarczyk Z. (1988). Obronność Poznania w latach 1253-1793. Poznań.

Polak Z. (2011). Płock średniowieczny - kontynuacja czy nowa jakość? [in:] Płock wczesnośredniowieczny, ed. A. Gołembnik, Warszawa, pp. 311378 .

Rębkowski M. (2001). Pierwsze lokacje miast w księstwie zachodniopomorskim. Przemiany przestrzenne i kulturowe. Kołobrzeg.

Rocznik kapituły gnieźnieńskiej 1192-1247. (1962). [in:] Roczniki wielkopolskie, ed. B. Kürbis in cooperation with G. Labuda, J. Luciński and R. Walczak, Warszawa, pp. 1-20.

Rocznik kapituły poznańskiej. (1962). [in:] Roczniki wielkopolskie, ed. B. Kürbis, cooperation G. Labuda, J. Luciński, R. Walczak, Warszawa, pp. 21-78.

Rubczyński W. (1886). Wielkopolska pod rządami synów Władysława Odonica (1239-1279). Rocznik Filarecki, 1, pp. 1-98.

Rzeźnik P. (2000). Gród wrocławski około roku 1000. [in:] Śląsk około roku 1000, ed. M. Młynarska-Kaletynowa, E. Małachowicz, Wrocław, pp. $139-148$.

Samsonowicz H. (1980). Tendencje rozwoju sieci miejskiej w Polsce późnośredniowiecznej. Kwartalnik Historii Kultury Materialnej, 28, no. 3, pp. 341-348.

Sawicki T. (2001). Wczesnośredniowieczny zespół grodowy w Gnieźnie. [in:] Gniezno w świetle ostatnich badań archeologicznych Nowe fakty. Nowe interpretacje, ed. Z. Kurnatowska, Poznań, pp. 87-126.

Sawicki T. (2001). Z badań nad zamkiem książęcym na Górze Lecha w Gnieźnie. [in:] Gniezno w świetle ostatnich badań archeologicznych. Nowe fakty. Nowe interpretacje, ed. Z. Kurnatowska, Poznań, pp. 221-241.

Spominki poznańskie. (1962). [in:] Roczniki wielkopolskie, ed. B. Kürbis, cooperation G. Labuda, J. Luciński, R. Walczak, Warszawa 1962, pp. 123126.

Spors J. (1974). Agresja brandenburska wobec Wielkopolski do 1278 roku. Roczniki Historyczne, 40, pp. 107-121.

Szymczak J. (2012). Źródła pisane do dziejów średniowiecznej Łęczycy. [in:] Źródła, wykopaliska mapy. Źródła do dziejów Łęczycy, ed. L. Sztompka, M. Żemigała, Łęczyca, pp. 11-40.

Trzeciecki M. (2011). Gród na Wzgórzu Tumskim. [in:] Płock wczesnośredniowieczny, ed. A. Gołembnik, Warszawa, pp. 101-148.

Trzeciecki M. (2011). Początki Płocka. [in:] Płock wczesnośredniowieczny, ed. A. Gołembnik, Warszawa, pp. 55-100.

Woźniak M. (2007). Inowrocław - stanowiska 2, 20 i 6 (AZP 44-40 st. na obszarze 45, 46 i 47) sprawozdanie z nadzorów archeologicznych oraz z ratowniczych badań archeologicznych prowadzonych w związku z przebudową skrzyżowania w ciągu drogi krajowej nr 15 w Inowrocławiu. Inowrocław, text stored in Jan Kasprowicz Museum in Inowrocław.

Woźniak M. (2012). Inowrocław stanowisko 20 (AZP 44-40 st. na obszarze 46) sprawozdanie z nadzorów archeologicznych. Inowrocław, opracowanie w zbiorach Muzeum Jana Kasprowicza w Inowrocławiu.

Woźniak M. (2014). Inowrocław - stanowisko 6 sprawozdanie z ratowniczych badań wyprzedzających w roku 2014 (obszar AZP 44-40/189). Inowrocław, text stored in Jan Kasprowicz Museum in Inowrocław.

Zientara B. (1997). Henryk Brodaty i jego czasy, afterword by M. Dygo, Warszawa. 